\title{
Investigation of Gamma-Emitting Natural Radioactive Contents in Three Types of Vernonia Consumed in Cameroon
}

\author{
Thomas B. Makon ${ }^{1}$, Robert Martin Nemba ${ }^{1}$, Pascal Tchokossa ${ }^{2 *}$ \\ ${ }^{1}$ Département de Physique, Faculté des Sciences, Université de Yaoundé I, Yaoundé, Cameroun \\ ${ }^{2 *}$ Department of Physics, Obafemi Awolowo University, Ile-Ife, Nigeria \\ E-mail: ptchokos@yahoo.com \\ Received March 24, 2011; revised April 28, 2011; accepted June 2, 2011
}

\begin{abstract}
The specific activity concentration and the derived Annual Effective Dose (AED) in three types of vernonia cultivated and consumed within and outside Cameroon were measured by means of a well-calibrated high-purity germanium detector. Vernonia samples were collected directly from the production farms, oven-dried to a constant mass, crushed, sieved and sealed for at least a month before analysis. The specific activity of ${ }^{238} \mathrm{U}$ in the three types of vernonia ranged from $20-50 \mathrm{~Bq} \cdot \mathrm{kg}^{-1}$ with an average of $42 \pm 15 \mathrm{~Bq} \cdot \mathrm{kg}^{-1}$, ${ }^{232} \mathrm{Th}$ from $9-22 \mathrm{~Bq} \cdot \mathrm{kg}^{-1}$ with an average of $17 \pm 7 \mathrm{~Bq} \cdot \mathrm{kg}^{-1}$ while ${ }^{40} \mathrm{~K}$ ranged from $115-460 \mathrm{~Bq} \cdot \mathrm{kg}^{-1}$ with an average of $302 \pm 36 \mathrm{~Bq} \cdot \mathrm{kg}^{-1}$. The average AED for ${ }^{40} \mathrm{~K},{ }^{238} \mathrm{U}$ and ${ }^{232} \mathrm{Th}$ were $0.15,0.92$ and $0.92 \mu \mathrm{Sv} \cdot \mathrm{y}^{-1}$ respectively. ${ }^{238} \mathrm{U}$ and ${ }^{232} \mathrm{Th}$ show the same trends both for the regional distribution of the radioactivity content and the AED. The discrepancies in our data can be attributed to many factors such as geological formation, foliar deposition, type and age of the plant, etc. Although the results obtained represent only some fractions of the standard limit, but they are within some range obtained in other countries.
\end{abstract}

Keywords: Radionuclides, Specific Activity, Dose, Vernonia, Gamma-Ray, Cameroon

\section{Introduction}

Exposure to ionizing radiation is generally regarded as undesirable at all levels although no harmful effects are known to follow very low-level exposures. Recently, considerable attention has been given to low-level exposure arising from naturally occurring radionuclides, particularly ${ }^{238} \mathrm{U},{ }^{232} \mathrm{Th}$, their decay products and ${ }^{40} \mathrm{~K}$. Natural radiation sources are the very important and they deliver the highest radiation dose to which human beings are exposed [1-3]. Natural radionuclides are present in air breathed by humans, in food [4], drinking water [5,6] as well as the ground from which human settlements are built [7]. When ingested or inhaled, naturally occurring radionuclides are distributed among body organs according to the metabolism of the element involved, which normally exhibits varying sensitivities to radiation [8]. Radioelements contents have been measured in various food and drinking water samples by several methods, but their concentrations differ from one place to another. Previous studies have shown that there are three food categories, namely: fish and shellfish, cereals (excluding rice) and vegetables, found to be the main contributors to the daily intakes [9].

Thus, varying doses and risks result from the consumption and the exposure to these radionuclides. Cameroon's population, whose majority is rural, feeds mainly on farm products based principally on vegetables.

It is noted that one of the major direct contaminations of man by ionizing radiations is done through the food chain. So, accurate estimation of the occurrence of natural radionuclides in foods will provide information from which the estimation of the average radiation exposure of the public in some localities can be made. Also, the knowledge of intakes of some radionuclides (such as ${ }^{238} \mathrm{U}$ and ${ }^{232} \mathrm{Th}$ ) is important for estimating the metabolic parameters of uptake and retentions of those radioelements in human body $[9,10]$. The leaves which constitute the eatable part of the plant, are not only consumed in the whole country Cameroon with a consumption rate of about $40 \%$, but exported to the neighbouring countries like Gabon, Equatorial Guinea and Central Africa Republic. To the best of our knowledge, there is no published or on-going research of radionuclides 
concentration in this plant in Cameroon and the present investigation is the first systematic effort to provide data on this aspect.

The purpose of this study is to identify radioelements contained in the edible vernonia cultivated in Cameroon, evaluate their specific activity concentration, and hence derive the Annual Effective Dose (AED) resulting from their consumption. The result would therefore constitute a contribution to the establishment of a standard database of the natural radioactivity of edible plants in Cameroon.

\section{Materials and Methods}

\subsection{Study Area}

Cameroon has a population of about 19,000,000 peoples as adapted by the recent headcount and a land mass area of $475,440 \mathrm{~km}^{2}$. The study area is located within the country between the latitude $1^{\circ} 71^{\prime} 0^{\prime \prime} \mathrm{N}$ and $6^{\circ} 71^{\prime} 0^{\prime \prime} \mathrm{N}$, and the longitude $8^{\circ} 71^{\prime} 0^{\prime \prime} \mathrm{E}$ and $13^{\circ} 71^{\prime} 0^{\prime \prime} \mathrm{E}$, in the northern hemisphere precisely in Central Africa as shown in Table 1 and Figure 1. It shares boundaries with the East province in the East, Adamawa in the North, Republic of Nigeria and the Atlantic Ocean in the West, and Equatorial Guinea and Gabon in the South. The area is tropical in nature with two climatic seasons viz: wet season which begins in March/April and ends in October with a break in August, and the dry season which begins in November and ends in March. The soil of the area is generally lateritic with some clay intercalation, while the geology of the area is essentially crystalline basement complex with dominant rock suites being granite gneisses charnokites [11].

\subsection{Sample Collection}

The main source of anthropogenic radionuclide exposure of the indigenous population of this area is environmental contamination of soil, vegetation and water. Information on the radioactivity content, in food products consumed by the population on the structure and composition of the inhabitant's was needed. The environmental sampling focused on the various foodstuffs constituting the indigenous population's diet, namely the consumption of vegetables especially vernonia, since there is a great belief that the whole plant is used for therapeutic needs in most parts of African. The vernonia is an asteraceae with bitter leaves, commonly called "ndole"; it generally occurs in three species namely, Amygdalina; Calvoana and Richardiana. The essential differentiation lies at the level of leaf morphologies, and the population eats them without any distinction.

A total number of 63 samples of various vernonia were collected between 14th May and 12th August 2003 from nine major supply towns of the country, where different types of this plant exist and whose consumption rate is very significant, directly from the agricultural farms, owned by the authors and some indigenes (as listed in Table 1 and shown in Figure 1).

In each town, sample collection was concentrated in those vernonia species. The leaves were collected directly from the plant at two different stages namely: when the leaves have just started budding and again when the leaves are about to shed. They were oven-dried under a temperature of $87^{\circ} \mathrm{C}$ within one day (24 hours) [12], and were withdrawn, then crushed and sieved using a $2 \mathrm{~mm}$ sieve mesh. All the samples were placed thereafter in a vertical cylindrical plastic container named Marinelli beaker, previously washed, rinsed with diluted $\mathrm{HCl}$ and dried, and sealed for at least four weeks to allow a sufficient time for ${ }^{238} \mathrm{U}$ and ${ }^{232} \mathrm{Th}$ to attain a state of secular radioactive equilibrium with their corresponding progenies prior to gamma spectroscopy [12-15].

\subsection{Instrumentation}

The counting equipment used consists of a Canberra vertical cylindrical high-purity coaxial germanium (HPGe) detector with model GC2018-7500 and serial number $b$ 87063, enclosed in a $100 \mathrm{~mm}$ thick lead shield. The HPGe detector was connected to a Canberra computer-assisted Multichannel analyzer (MCA). Accurate energy and efficiency calibrations of the gammaspectrometry system were made using a standard source of radionuclides supplies by the International Energy Agency (IAEA), Vienna, Austria and the Isotope Products Laboratories, Burbank California, USA. The descriptions of the gamma spectrometry system as well as more details on the calibration are well documented [13,14]. An empty Marinelli beaker with the same geometry as that of the sample was used as background. The counting time for accumulating spectral for both the samples and background was set at 36,000 s. Each container was counted twice in order to check the stability of the counting system. The gamma spectroscopy analysis employed in this work was based on a computer program SAMPO 90 which matched $\gamma$-energy at various energy levels to a library of possible isotopes. This data analysis routine subtracted a linear background distribution from pulse-height spectra of both the sample and the background in addition to the net background peak area being subtracted from the corresponding net peak area for a particular radionuclide. The resolution of the HPGe detector made it possible to identify a wide spectrum of $\gamma$-rays in the sample and the photopeaks observed with regularity in the samples were identified as belonging to the radioactive decay series headed by ${ }^{238} \mathrm{U}$ and ${ }^{232} \mathrm{Th}$ and 
Table 1. Sampling locations.

\begin{tabular}{cccrrr}
\hline Location Number & Sampling Locations & Region & Latitude & Longitude & Nos of Samples Collected \\
\hline 1 & Yaounde & Center & $3^{\circ} 52^{\prime} 0^{\prime \prime} \mathrm{N}$ & $11^{\circ} 31^{\prime} 0^{\prime \prime} \mathrm{E}$ & 10 \\
2 & Ezeka & & $3^{\circ} 41^{\prime} 50^{\prime \prime} \mathrm{E}$ & $10^{\circ} 54^{\prime} 5^{\prime \prime} \mathrm{E}$ & 15 \\
3 & Douala & Littoral & $4^{\circ} 3^{\prime} 1^{\prime \prime} \mathrm{N}$ & $9^{\circ} 42^{\prime} 0^{\prime \prime} \mathrm{E}$ & 8 \\
4 & Edéa & $3^{\circ} 48^{\prime} 0^{\prime \prime} \mathrm{N}$ & $10^{\circ} 8^{\prime} 0^{\prime \prime} \mathrm{E}$ & 6 \\
5 & Bamenda & North-West & $5^{\circ} 56^{\prime} 0^{\prime \prime} \mathrm{N}$ & $10^{\circ} 10^{\prime} 0^{\prime \prime} \mathrm{E}$ & 7 \\
6 & Sangmelima & South & $2^{\circ} 56^{\prime} 0^{\prime \prime} \mathrm{N}$ & $11^{\circ} 59^{\prime} 0^{\prime \prime} \mathrm{E}$ & 4 \\
7 & Lolodorf & & $3^{\circ} 26^{\prime} 70^{\prime \prime} \mathrm{E}$ & $10^{\circ} 26^{\prime} 8^{\prime \prime} \mathrm{E}$ & 5 \\
8 & Buea & South-West & $4^{\circ} 9^{\prime} 33^{\prime \prime} \mathrm{N}$ & $9^{\circ} 14^{\prime} 12^{\prime \prime} \mathrm{E}$ & 4 \\
9 & Limbe & & & $4^{\circ} 0^{\prime} 46^{\prime \prime} \mathrm{N}$ & $9^{\circ} 13^{\prime} 13^{\prime \prime} \mathrm{E}$ \\
\hline
\end{tabular}

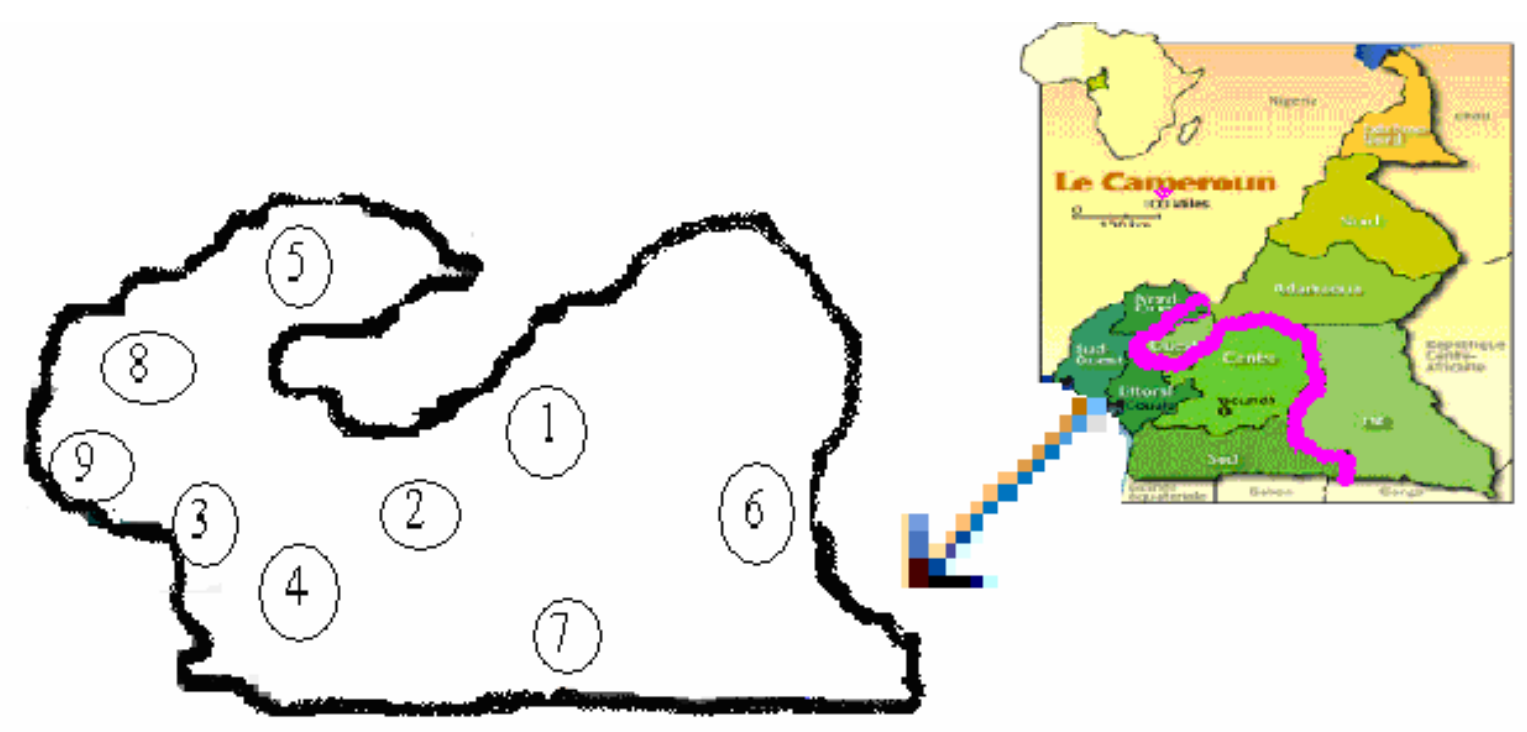

Figure 1. Map showing the study area.

a non-series radionuclide ${ }^{40} \mathrm{~K}$ respectively. The other radionuclides, if present, appeared infrequently at low levels, or occurred at levels below the minimum detectable limit (MDL). The measurement error was about $30 \%$ and the method used for this study had the following MDLs: $0.9 \mathrm{~Bq} \cdot \mathrm{kg}^{-1}$ for ${ }^{238} \mathrm{U}, 0.6 \mathrm{~Bq} \cdot \mathrm{kg}^{-1}$ for ${ }^{232} \mathrm{Th}$ and $2.6 \mathrm{~Bq} \cdot \mathrm{kg}^{-1}$ for ${ }^{40} \mathrm{~K}$, all at a measuring time of $36,000 \mathrm{~s}$. The activity concentration of ${ }^{40} \mathrm{~K}$ was determined directly by its $\gamma$-line of $1460.8 \mathrm{keV}$, while that of ${ }^{238} \mathrm{U}$ and ${ }^{232} \mathrm{Th}$ were estimated by measuring the $\gamma$-ray lines of $609.3 \mathrm{keV}$ of ${ }^{214} \mathrm{Bi}$ and $1120.3 \mathrm{keV}$ of ${ }^{214} \mathrm{Bi}$; and 969.0 $\mathrm{keV}$ of ${ }^{228} \mathrm{Ac}$ and $583.0 \mathrm{keV}$ of ${ }^{208} \mathrm{Tl}$ respectively.

\section{Results and Discussion}

\subsection{Radioactivity Content in Leaves}

The distribution of the average activity concentrations of the radionuclides determined from the measurement of the various types of vernonia analyzed is shown in Table 2 and Figure 2. From this table, the specific activity concentrations of ${ }^{40} \mathrm{~K}$ ranged from $115-429 \mathrm{~Bq} \cdot \mathrm{kg}^{-1}$ with an average of $292 \pm 35 \mathrm{~Bq} \cdot \mathrm{kg}^{-1}$ in amygdalina; $187-460$ $\mathrm{Bq} \cdot \mathrm{kg}^{-1}$ with an average of $334 \pm 40 \mathrm{~Bq} \cdot \mathrm{kg}^{-1}$ in calvoana and $226-293 \mathrm{~Bq} \cdot \mathrm{kg}^{-1}$ with an average of $263 \pm 33$ $\mathrm{Bq} \cdot \mathrm{kg}^{-1}$ in richardiana. The overall concentration of ${ }^{40} \mathrm{~K}$ ranged from 115 to $460 \mathrm{~Bq} \cdot \mathrm{kg}^{-1}$ with an average of $302 \pm$ $36 \mathrm{~Bq} \cdot \mathrm{kg}^{-1}$. Potassium-40 is the most relatively abundant radioelement of all species. This is not a surprise because ${ }^{40} \mathrm{~K}$ is an essential biological element. Its concentration in human tissue is about $63 \mathrm{~Bq} \cdot \mathrm{kg}^{-1}$ and ranged between $40-600 \mathrm{~Bq} \cdot \mathrm{kg}^{-1}$ in food [16]. This concentration is under close metabolic (homeostatic) control [17]; and its variations in dietary composition do not influence significantly the radiation dose received. However its concentrations are not the same in all vernonia. It is highest in calvoana and lowest in richardiana. It is realised that all the samples present potassium-40 concentrations higher than $200 \mathrm{~Bq} \cdot \mathrm{kg}^{-1}$, but lower than those reported by other researchers elsewhere $[18,19]$ and in other species [20].

The specific activity concentrations of ${ }^{238} \mathrm{U}$ ranged from $20-50 \mathrm{~Bq} \cdot \mathrm{kg}^{-1}$ with an average of $42 \pm 15 \mathrm{~Bq} \cdot \mathrm{kg}^{-1}$ in amygdalina; $40-48 \mathrm{~Bq} \cdot \mathrm{kg}^{-1}$ with an average of $45 \pm$ 
Table2. Specific activity concentration in various types of vernomia $\left(\mathrm{Bq}^{\circ} \mathrm{kg}^{-1}\right)$.

\begin{tabular}{|c|c|c|c|c|c|c|}
\hline \multirow{2}{*}{ Types } & \multicolumn{2}{|c|}{${ }^{40} K$} & \multicolumn{2}{|c|}{${ }^{238} \mathbf{U}$} & \multicolumn{2}{|c|}{${ }^{232} \mathrm{Th}$} \\
\hline & Mean & Range & Mean & Range & Mean & Range \\
\hline Amygdalina & $292 \pm 35$ & $115-429$ & $42 \pm 15$ & $20-50$ & $17 \pm 7$ & $9-20$ \\
\hline Calvoana & $334 \pm 40$ & $187-460$ & $45 \pm 16$ & $40-48$ & $17 \pm 6$ & $15-19$ \\
\hline Richardiana & $263 \pm 33$ & $226-293$ & $32 \pm 11$ & $29-35$ & $18 \pm 5$ & $13-22$ \\
\hline Average & $302 \pm 36$ & $115-460$ & $42 \pm 15$ & $20-50$ & $17 \pm 7$ & $9-22$ \\
\hline
\end{tabular}



Figure 2. Bar chart showing radioactivity content in the various types of vernonia.

$16 \mathrm{~Bq} \cdot \mathrm{kg}^{-1}$ in calvoana and $29-35 \mathrm{~Bq} \cdot \mathrm{kg}^{-1}$ with an average of $32 \pm 11 \mathrm{~Bq} \cdot \mathrm{kg}^{-1}$ in richardiana. The overall concentration of ${ }^{238} \mathrm{U}$ ranged from 20 to $50 \mathrm{~Bq} \cdot \mathrm{kg}^{-1}$ with an average of $42 \pm 15 \mathrm{~Bq} \cdot \mathrm{kg}^{-1}$; while the highest activity concentration was recorded in calvaona. The activity concentration for ${ }^{238} \mathrm{U}$ is relatively higher than that obtained in the leaves of the same plants in India [20].

The specific activity concentrations of ${ }^{232} \mathrm{Th}$ ranged from $9-19 \mathrm{~Bq} \cdot \mathrm{kg}^{-1}$ with an average of $17 \pm 7 \mathrm{~Bq} \cdot \mathrm{kg}^{-1}$ in amygdalina; $15-19 \mathrm{~Bq} \cdot \mathrm{kg}^{-1}$ with an average of $17 \pm 6$ $\mathrm{Bq} \cdot \mathrm{kg}^{-1}$ in calvoana and $13-22 \mathrm{~Bq} \cdot \mathrm{kg}^{-1}$ with an average of $18 \pm 5 \mathrm{~Bq} \cdot \mathrm{kg}^{-1}$ in richardiana, while the overall concentration of ${ }^{232} \mathrm{Th}$ ranged from 9 to $22 \mathrm{~Bq} \cdot \mathrm{kg}^{-1}$ with an average of $17 \pm 7 \mathrm{~Bq} \cdot \mathrm{kg}^{-1}$. The activity concentration for ${ }^{232} \mathrm{Th}$ in all the vernonia analysed is relatively equal but higher than what was reported by Shawki in the plants with the turn of a site of production of uranium in Wyoming in the USA [21].

Both ${ }^{40} \mathrm{~K}$ and ${ }^{238} \mathrm{U}$ activity concentrations were highest in calvaona, followed by amygdalina and later by richardiana. This trend was reversed for ${ }^{232} \mathrm{Th}$. The relative high concentration of ${ }^{238} \mathrm{U}$ over ${ }^{232} \mathrm{Th}$ may be due to the fact that the acidity and wet condition at this site tend to enhance the solubility and availability of ${ }^{238} \mathrm{U}$ for plant intake. Also foliar deposition of pond water spray con- taining elevated ${ }^{238} \mathrm{U}$ concentration and subsequent foliar absorption may be another important uptake mechanism [21]. It is also interesting to note that the activity concentration in the leaves in their earlier days of life was significantly higher than when they were getting mature. This trend was observed in all the three radionuclides namely ${ }^{40} \mathrm{~K},{ }^{238} \mathrm{U}$ and ${ }^{232} \mathrm{Th}$ and in all the types of vernonia analysed as observed by Manigandan [22].

\subsection{Regional Distribution of Radioactivity}

The results of the regional distribution of radioactivity obtained are presented in Table 3 and Figure 3. The average activity concentration for ${ }^{40} \mathrm{~K},{ }^{238} \mathrm{U}$ and ${ }^{232} \mathrm{Th}$ is $307 \pm 39,37 \pm 12$ and $17 \pm 6 \mathrm{~Bq} \cdot \mathrm{kg}^{-1}$ in the center; $317 \pm$ $37,43 \pm 15$ and $16 \pm 5 \mathrm{~Bq} \cdot \mathrm{kg}^{-1}$ in the littoral; $263 \pm 35$, not detectable and $17 \pm 7 \mathrm{~Bq} \cdot \mathrm{kg}^{-1}$ in the north-west; 386 $\pm 34,45 \pm 18$ and $18 \pm 9 \mathrm{~Bq} \cdot \mathrm{kg}^{-1}$ in the south; and finally $212 \pm 27,49 \pm 19$ and not detectable in the south-west respectively. The highest activity concentration of ${ }^{40} \mathrm{~K}$ was found in north-west, while the lowest was insouth-west; ${ }^{238} \mathrm{U}$ was not detected in north-west and it was highest in south-west; contrary ${ }^{232} \mathrm{Th}$ was not de tected in south-west and highest in the center. In fact, the the Atlantic ocean and it is made up of beach sands (un- 
Table 3. Regional distribution of radioactivity content in the vernonia analyzed $\left(\mathrm{Bq}^{\mathrm{k}} \cdot \mathrm{kg}^{-1}\right)$.

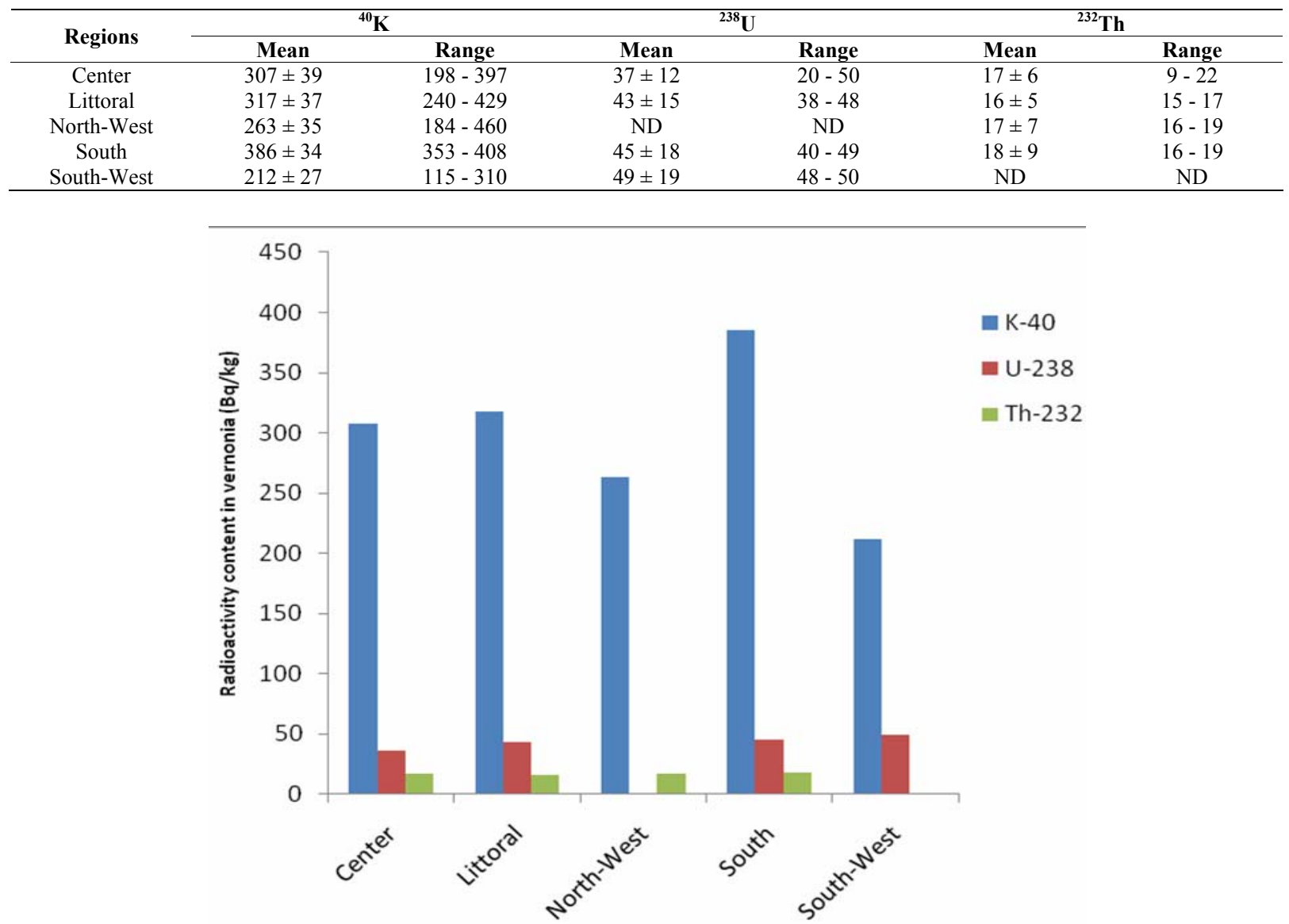

Figure 3. Bar chart showing regional distribution of radioactivity content in the vernonia analyzed $\left(B q \cdot \mathrm{kg}^{-1}\right)$.

consolidated) that may wash away potassium and hencereduced its activity concentration as obtained elsewhere [23].

The high specific activity of ${ }^{40} \mathrm{~K}$ in north-west would be understandable by the fact that, the soil is constituted by granite which usually accumulates potassium-40 [23].

Other contributors may also be the atmospheric deposition of radionuclides on the leaves.

\subsection{Annual Effective Doses Due to Vernonia Ingestion.}

The Annual Effective Dose (AED) is a useful parameter that enables the radiation from different radionuclides and from different types and sources to estimate the radiation induced health effects associated with intake of radionuclides by the body. It is proportional to the total dose liberated by the radionuclides while residing in the various organs [24].

The AED from a single radionuclide $r$ in one foodstuff $\mathrm{f}$ is given by:

$$
H_{r_{f}}=\omega_{r} C_{r f} U_{f}
$$

where $H_{r f}$ is the effective dose by ingestion of nuclide $r(\mathrm{~Sv} / \mathrm{y})$,

$\omega_{r}$ is the effective dose conversion factor by ingestion of nuclide $r(\mathrm{~Sv} / \mathrm{Bq})$,

$C_{r f}$ is the activity concentration of nuclide $r$ in ingestion of the food $(\mathrm{Bq} / \mathrm{kg})$, and

$U_{f}$ is the food consumption rate $f(\mathrm{~kg} / \mathrm{y})$.

The calculations are based on the assumptions that each person takes food according to the consumption defined in the food balance sheets [25]. The AED from various radionuclides ingested in different types of vernonia with various radionuclides is obtained by summing up over all nuclides and all vernonia collected. The dose conversion factors per gram of ingestion of ${ }^{40} \mathrm{~K}$; ${ }^{238} \mathrm{U}$ and ${ }^{232} \mathrm{Th}$ are $6.2 \times 10^{-9}, 2.8 \times 10^{-7}$ and $6.9 \times 10^{-7}$ for adults [25-27]. The estimated AED and its regional distribution are shown in Tables 4 and 5 respectively, while Figures 4 and 5 illus trate these results. For ${ }^{238} \mathrm{U}$, the highest AED was obtained in calvoana while the lowest came from richardiana; ${ }^{232} \mathrm{Th}$ also shows the greater AED in richardiana and the smallest from amygdalina. Similarly, calvoana hasthe biggest AED deriving 
Table 4. Estimated Annual Effective Dose by ingestion of vernonia $\left(\mu \mathrm{Sv}^{\circ} \mathrm{y}^{-1}\right)$.

\begin{tabular}{|c|c|c|c|c|}
\hline Types of vernonia & ${ }^{40} \mathrm{~K}$ & ${ }^{238} \mathbf{U}$ & ${ }^{232} \mathrm{Th}$ & Grand Total \\
\hline Amygdalina & 0.14 & 0.92 & 0.91 & 1.97 \\
\hline Calvoana & 0.16 & 1.00 & 0.91 & 2.07 \\
\hline Richardiana & 0.13 & 0.70 & 0.96 & 1.79 \\
\hline Average & 0.15 & 0.92 & 0.92 & 1.94 \\
\hline Total & 0.43 & 2.62 & 2.78 & 5.83 \\
\hline
\end{tabular}

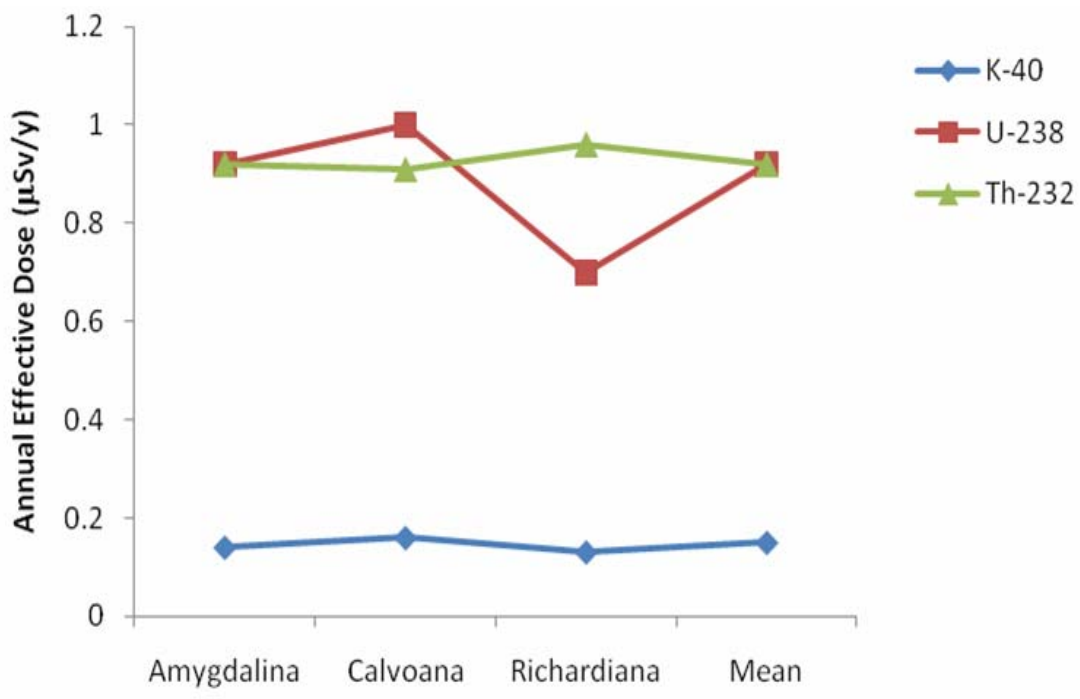

Figure 4. Annual Effective Dose of the vernonia analysed.

Table 5. Regional distribution of Annual Effective Dose $\left(\mu \mathrm{Sv} \cdot \mathrm{y}^{-1}\right)$.

\begin{tabular}{cccc}
\hline Region & ${ }^{40} \mathbf{K}$ & ${ }^{238} \mathbf{U}$ & ${ }^{232} \mathbf{T h}$ \\
\hline Center & 0.15 & 0.80 & 0.91 \\
Littoral & 0.15 & 0.95 & 0.85 \\
North-West & 0.13 & 0 & 0.93 \\
South & 0.19 & 0.99 & 0.96 \\
South-West & 0.10 & 1.08 & 0 \\
\hline
\end{tabular}

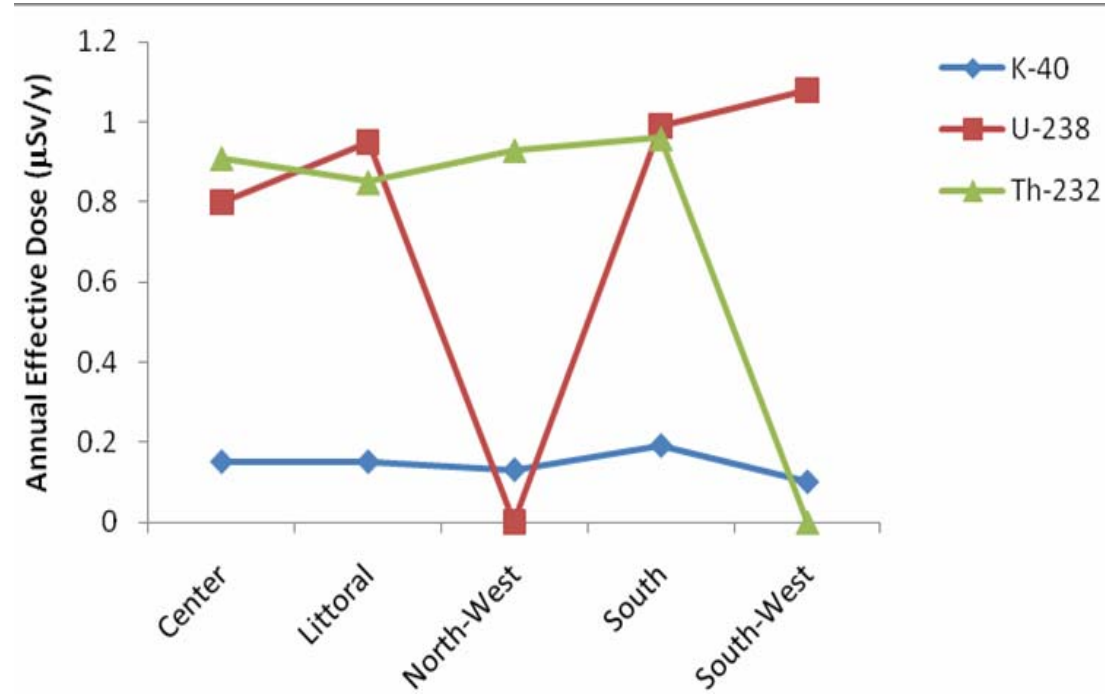

Figure 5. Regional Distribution of Annual Effective Dose in various vernonia.

from ${ }^{40} \mathrm{~K}$ and the smallest from richardiana. The same trends are also observed when considering the AED re- sulting from the three nuclides. Calvoana $2.07 \mu \mathrm{Sv} \cdot \mathrm{y}^{-1}$, followed by amygdalina $1.97 \mu \mathrm{Sv}^{-1} \mathrm{y}^{-1}$ and lastly rich- 
ardiana $1.79 \mu \mathrm{Sv} \cdot \mathrm{y}^{-1}$. The total estimated AED obtained were 1.97, 2.07 and $1.74 \mu \mathrm{Sv} \cdot \mathrm{y}^{-1}$ for amygdalina, calvoana and richardiana respectively. The committed effective dose resulting from ingestion of ${ }^{238} \mathrm{U}$ and ${ }^{232} \mathrm{Th}$ combined in normal background areas was $6.3 \mu \mathrm{Sv}$ and $11 \mu \mathrm{Sv}$ respectively [28]. Therefore, the estimated average AED of ${ }^{238} \mathrm{U}$ and ${ }^{232} \mathrm{Th}$ from all types of vernonia analyzed represent $15 \%$ and $8.4 \%$ of the said limits. The estimated AED of ${ }^{40} \mathrm{~K}$ was $0.15 \mu \mathrm{Sv} \cdot \mathrm{y}^{-1}$ and it comprised $0.01 \%$ of the annual dose (AD) limit of $10^{3} \mu \mathrm{Sv}^{\cdot \mathrm{y}^{-1}}$ for the general public [26]. The estimated total AED received from ${ }^{238} \mathrm{U},{ }^{232} \mathrm{Th}$ and ${ }^{40} \mathrm{~K}$ due to consumption of vernonia by the inhabitants $(5.83 \mu \mathrm{Sv})$ was just about $2.01 \%$ of the total exposure per person resulting from ingestion of terrestrial radioisotopes $(290 \mu \mathrm{Sv})$ as proposed by the UNSCEAR [28]. ${ }^{232} \mathrm{Th}$ contributed the highest to the mean AED, while the least contributor was ${ }^{40} \mathrm{~K}$. This result is in agreement with other published studies [29-32].

Also the highest AED deriving from uranium and thorium content was obtained in South-west and South with a values of $1.08 \mu \mathrm{Sv} \cdot \mathrm{y}^{-1}$ and $0.96 \mu \mathrm{Sv} \cdot \mathrm{y}^{-1}$ respectively, while the AED was zero for both radionuclides in Northwest and South-west. In fact, North-west is made up of series of mountains among are old volcanoes, resulting in the possible radionuclides depositions that are transported through the erosion process to the South and South-west located almost at the sea level.

\section{Conclusions and Recommendations}

Baseline data on the concentrations and derived annual effective doses of the natural radionuclides, namely ${ }^{40} \mathrm{~K}$, ${ }^{238} \mathrm{U}$ and ${ }^{232} \mathrm{Th}$ in vernonia produced in Cameroon have been established. The data obtained showed that, while ${ }^{40} \mathrm{~K}$ accounting the overall highest contribution of $460 \pm$ $48 \mathrm{~Bq} \cdot \mathrm{kg}^{-1}$, the highest for ${ }^{238} \mathrm{U}$ was found in calvoana and that of ${ }^{232} \mathrm{Th}$ was recorded in richardiana with a value of $50 \pm 20 \mathrm{~Bq} \cdot \mathrm{kg}^{-1}$ and $22 \pm 6 \mathrm{~Bq} \cdot \mathrm{kg}^{-1}$ respectively. Contrary, ${ }^{238} \mathrm{U}$ and ${ }^{232} \mathrm{Th}$ were the major contributors of the AED with an average values of $0.92 \mu \mathrm{Sv} \cdot \mathrm{y}^{-1}$ for both. The regional distribution of the radioactivity content and derived AED revealed that the southern region recorded the highest, while the least was found in North-west for ${ }^{40} \mathrm{~K}$ and ${ }^{238} \mathrm{U}$. Detected levels for ${ }^{40} \mathrm{~K}$ in vernonia might be higher than its specific activities in other foodstuffs because potassium is more concentrated in leaves than in any other parts of the plant. The differences in the results were attributed to many factors such as geological formation of the soil, foliar deposition, species and age of the plant, etc. Although our results are still within the range of some works obtained in many countries, but Cameroon has the particularity in the sense that it is not only the food basket of many neighboring countries, but it is made up of several active and non-active volcanoes, the most recent being the Lake Nyos eruption that happen in 1986. It is therefore recommended that regular monitoring of various matrices in this environment is paramount. Taking into account the mutagenic and carcinogenic effects of some of the elements of the radioactive chain of these radionuclides, their significant presence is a challenge to the authorities for the protection of the inhabitants.

\section{Acknowledgements}

The authors wish to express their sincere gratitude to the International Atomic Energy Agency for providing standard radioactive sources used for the calibration of the detector system, to the Director, Centre for Energy Research and Development (CERD) Ile-Ife, Osun StateNigeria for providing its laboratory for Gamma Spectrometry analysis, and to Dr. Chijoke Uwasomba of the Department of English, Obafemi Awolowo University, Ile-Ife, for proofread this manuscript.

\section{References}

[1] B. Marouf, S. A. Mohamad and J. S. Taha, "Assessment of Exposure Rate and Collective Effective Dose Equivalent in the City of Baghdad Due to Natural Gamma Radiation," The Science of the Total Environment, Vol. 133, 1993, No. 1-2, pp. 133-137

[2] C. A. Aborisade, J. B. Olomo and P. Tchokossa, "Radioactivity in Palm Oil Produced at Olabisi Ogunbanjo University Oil Mill," Nigeria Journal of Physics, Vol. 15, No. 1, 2003, pp. 17-19.

[3] A. Achudume, B. Onibere, F. Aina and P. Tchokossa, "Induction of Oxidative Stress in Male Rats Subchronically Exposed to Electromagnetic Fields at Non-thermal Intensities," Journal of Electromagnetic Analysis \& Application, Vol. 2, 2010, pp. 507-512.

[4] O. A. Osibote, J. B. Olomo, P. Tchokossa and F. A. Balogun, "Radioactivity in Milk Consumed in Nigeria 10 Years after Chernobyl Reactor Accident," Nuclear Instruments and Methods in Physics Research A, Vol. 422, 1999, No. 1-3, pp. 778-783.

[5] P. Tchokossa, J. B. Olomo and O. A. Osibote, "Radioactivity in Community Water Supplies in Ife-Central and Ife-East Local Government Areas of Osun State, Nigeria," Nuclear Instruments and Methods in Physics Research A, Vol. 422, No. 1-3, 1999, pp. 784-789. doi:10.1016/S0168-9002(98)00997-8

[6] G. O. Avwiri, P. Tchokossa and C. E. Mokobia, "Natural Radionuclides in Borehole Water in Port Harcourt, Rivers State, Nigeria," Radiation Protection and Dosimetry, Vol. 123, No. 4, 2007, pp. 509-514.doi:10.1093/rpd/nc1526

[7] J. B. Olomo, P. Tchokossa and C. A. Aborisade, "Study 
of Radiation Protection Guidelines in the Use of Building Materials for Urban Dwellings in South-West Nigeria," Nigeria Journal of Physics, Vol. 15, No. 1, 2003, pp. 713.

[8] C. R. Cothern, W. I. Lappenbusch and M. Jacqueline, "Drinking Water Contribution to Natural Background Radiation," Health Physics, Vol. 50, No. 1, 1986, pp. 3347. doi:10.1097/00004032-198601000-00002

[9] M. A. Misdaq and W. Bourzik, "Evaluation of Annual Committed Effective Doses to Members of the Public in Morocco Due to 238U and 232Th in Various Food Materials," Journal of Radiological Protection, Vol. 24, No. 4, 2004, pp. 391-399. doi:10.1088/0952-4746/24/4/003

[10] M. K. Fasasi, P. Tchokossa, J. O Ojo and F. A. Balogun, "Occurrence of Natural Radionuclides and Fallout Cesium-137 in Dry-Season Agricultural Land of South Western Nigeria," Journal of Radioanalytical and $\mathrm{Nu}$ clear Chemistry, Vol. 240, No. 3, 1999, pp. 949-952. doi:10.1007/BF02349880

[11] T. Schlüter and M. H. Trauth, "Geological Atlas of Africa: With Notes on Stratigraphy, Tectonics, Economic Geology, Geohazards, Geosites and Geoscientific Education of Each Country," 2nd Edition, Springer, Berlin, 2008.

[12] IAEA International Atomic Energy Agency, "Measurement of Radionuclides in Food and the Environment," A Guidebook Technical Reports Series No 295, IAEA, Vienna, 1989.

[13] P. Tchokossa, "Radiological Study of Oil and Gas Producing Areas in Delta State, Nigeria," Ph.D. Thesis, Department of Physics, Obafemi Awolowo University, Ile-Ife, 2006.

[14] J. B. Olomo, M. K Akinloye and F. A. Balogun, "Distribution of Gamma Emitting Natural Radionuclides in Soils and Water around Nuclear Research Establishments in Ile-Ife Nigeria," Nuclear Instruments and Methods in Physics Research A, Vol. 353, No. 1-3, 1994, pp. 553557. doi:10.1016/0168-9002(94)91721-3

[15] Environmental Protection Agency and Food and Drug Administration, "Radionuclides in Institutional Diet Samples," Radiation Data Report, Vol. 15, 1974, p. 126.

[16] International Atomic Energy Agency, "Natural and Induced Radioactivity in Food," IAEA-TECDOC-1287, April 2002.

[17] United Nations Scientific Committee on the Effects of Atomic Radiations, "Ionizing Radiation: Sources and Biological Effects," New York, 1982.

[18] H. Vaelasco, J. Juri, M. A. Beelli and U. Sansone, "Temporal Trends of 137Cs And 40K Activity Flux from Soil to Plant in Grassland Ecosystems," Journal of Environmental Radioactivity, Vol. 71, No. 3, 2004, pp. 225-241. doi:10.1016/S0265-931X(03)00171-1

[19] International Atomic Energy Agency, "Summary Report on Post Accident Review Meeting on the Chernobyl Accident Safety Series," 75-INSAG-1 IAEA, Vienna, 1986.

[20] N. Karunakara, H. M. Smashekarappa, Y. Narayana, D. N. Avadhani, H. M. Mahesh and K. Siddappa, "226Ra, $40 \mathrm{~K}, 7 \mathrm{Be}$ Activity Concentrations in Plants in the Envi- ronment of Kaiga, India," Journal of Environmental Radioactivity, Vol. 65, 2003, pp. 255-266. doi:10.1016/S0265-931X(02)00101-7

[21] A. I. Shawki and W. Whickers, "Comparative Uptake of U and Th by Native Plants at a U Production Site," Health Physics, Vol. 54, No. 4, 1988, pp. 413-419. doi:10.1097/00004032-198804000-00004

[22] P. K. Maniganda, "Activity Concentration of Radionuclides in Plants in the Environment of Western Ghats," Iran Journal of Radiation Research, Vol. 7, No. 2, 2009, pp. 85-90.

[23] National Council on Radiation Protection and Measurements, "NCRP Report No. Bethesda MD 20814," 1994.

[24] N. N. Jibiri, I. P. Farai and S. K. Alausa, "Estimation of Annual Effective Dose Due to Natural Radioactive Elements in Ingestion of Foodstuffs in Tin Mining Area of Jos-Plateau, Nigeria," Journal of Environmental Radioactivity, Vol. 94, No. 1, 2007 , pp. 31 - 40. doi:10.1016/j.jenvrad.2006.12.011

[25] International Commission on Radiological Protection, "ICRP Publication72: Age Dependent Doses to Members of the Public from Intake of Radionuclides. Ingestion and Inhalation Dose Coefficients," Annals of the ICRP, Pergamon, Oxford, Vol. 26, No. 1, 1996.

[26] International Atomic Energy Agency, "International Basic Safety Standards for Protection against Ionising Radiation and for the Safety of Radiation Sources," Safety Series No. 115, IAEA Vienna, 1996.

[27] M. A. Misdaq and W. Bourzik, "Determination of Committed Effective Doses from Annual Intakes of $238 \mathrm{U}$ and 232Th from the Ingestion of Cereals, Fruits and Vegetables by Using CR-39 and LR-115 II SSNTD," Journal of Radioanalytical and Nuclear chemistry, Vol. 254, No. 3, 2002, pp. 551-555. doi:10.1023/A:1021650423883

[28] United Nations Scientific Committee on the Effects of Atomic Radiation, "Annex B: Exposures from Natural Radiation Sources," UNSCEAR 2000 Report, New York, 2000.

[29] A. Catalãn, J. C. Fernãndez-Aldecoa, J. HernãndezArmas, F. Hernãndez and M. I. Landeras, "Activity Concentrations and Mean Annual Effective Dose of Foodstuffs on the Island of Tenerife, Spain," Radiation Protection Dosimetry, Vol. 111, No. 2, 2000, pp. 205210.

[30] M. Asefi, A. A. Fathivand and J. Amidi, "Estimation of Annual Effective Dose from 226Ra and 228Ra Due to Consumption of Foodstuffs by Inhabitants of Ramsar City, Iran," Iran Journal of Radiation Research, Vol. 3, No. 1, 2005, pp. 7-48.

[31] M. S. Choi, X. J. Lin, S. A. Lee, W. Kim, H. D. Kang, S. H. Doh, D. S. Kim and D. M. Lee, "Daily Intake of Naturally Occurring Radioisotopes in Typical Korean Foods," Journal of Environmental Radioactivity, Vol. 86, 
2008, pp. 1-11.

[32] V. Changizi, Z. Jafarpoor and M. Naseri, "Measurement of 226Ra, 228Ra, 137Cs and 40K in Edible Parts of Two Types of Leafy Vegetables Cultivatedd in Te- hran Provine-Iran and Resultant Annual Ingestion Radiation Dose," Iran Journal of Radiation Research, Vol. 8, No. 2, 2010, pp. 103-110. 